\title{
How Do Agency Theory, Stewardship Theory and Intellectual Capital as a Solution for Agency Conflict?
}

\author{
Alni Rahmawati \\ Ph.D Student Economic and Business Faculty \\ Universitas Brawijaya Malang Indonesia \\ E-mail: alni_ra@yahoo.com \\ Moeljadi \\ UniversitasBrawijaya Malang Indonesia \\ Djumahir \\ UniversitasBrawijaya Malang Indonesia \\ Sumiati \\ Universitas Brawijaya Malang Indonesia
}

Received: March 18, 2018

doi:10.5296/jmr.v10i2.12843
Accepted: April 17, 2018

Published: April 17, 2018

URL: https://doi.org/10.5296/jmr.v10i2.12843

\begin{abstract}
The article aims to integrate agency theory, stewardship theory and intellectual capital in minimizing agencies conflict. The theories were approached by identifying organizational principles according to perspective of shareholders, then comparison of applications of agency theory, stewardship theory and intellectual capital contributing to the principal relationship with the agent in minimizing agencies conflict in order to contribute to enhancement of corporate value was discussed and empirical studies on perspectives of agency, stewardship and intellectual capital perspective specialized in human capital and structural capital were examined. The deep study of the theories concluded, it is necessary to integrate agency theory and stewardship theory and intellectual capital in effort of minimizing agencies conflict and enhancing corporate value. Further, it can be suggested that
\end{abstract}




\section{Macrothink}

Journal of Management Research

ISSN 1941-899X 2018, Vol. 10, No. 2

perspective of agency theory explains the importance of multi-principles framework, with perspectives of stewardship theory and intellectual capital showing a situation in which agent has the same interest as principle or to be motivated to make action for the sake of the best interest of the principal in minimizing agencies conflict and enhancing value of the company. Empirical literature can add more thoughts on agency issues integrated with stewardship theory and intellectual capital that can contribute to the study of the issues.

Keywords: Agency Theory, Stewardship Theory, Intellectual Capital, Corporate Value 


\section{Background of The Research}

Establishment of a company begins with innovative and creative ideas for development of the company and strives to be successful in long run. Generally, it starts from a business owned and managed individually by one person. Along with its growth and development, the business requires substantial capital by offering its shares to the public and the management is handled more professionally to enhance value of the business as its main goal reflected in prosperity of its shareholders. The business begins to create a policy, namely management of the company is run separately to achieve its main objectives. The Policy of company/business is influenced by agency theory, namely agency conflict starts to emerge between principal and agent. The agent will not act to maximize profits for shareholders unless governance structure is implemented appropriately in the company especially go public one for the benefit of shareholders (Jensen and Meckling 1976).

A study of agency conflict examines a conflict within a family firm, between family members of the firm owner about clarity between owner and manager or between active families, i.e. families who are participating in management of the firm and passive families, i.e. families of owner who do not participate in the firm, in which the active family may be less precise in allocating resources companies for the benefit of their own core families at the expense of other family branches (Blanco-Mazagatos, de Quevedo-Puente and Delgado-García, 2016). It will, according to some other researchers, also affect performance of the family-owned company (Basco, 2013; Schulze, Lubatkin, \& Dino, 2002 in Virginia Blanco, et al, 2016).

Development of family companies seen from one generation to the next showed that agency conflicts has been higher because of the growth of the families in each generation emphasized separation of ownership, poor control of owner to managers of the family company and increasing number of passive family groups of the owner (Miller et al., 2013), weaker familial bound between family members of the same generation and between different generations (Gersick, Davis, McCollom, \& Lansberg, 1997 ; Schulze et al., 2001,2002 ). Under the situation, stages of generation can increase agency conflict between active family groups and passive family group of the owner (Virginia Blanco, et al, 2016).

Stijn Van Puyvelde1, Ralf Caers, Cind Du Bois, and Marc Jegers (2012) stated that, in line with non-profit organizations, most non-profit organizations are characterized by separation of ownership and organizational management, so an explicit difference is found between manager who makes day-to-day decisions and organizational owner (Fama \& Jensen, 1983 in Stijn Van Puyveldel et.al. 2012). In addition to manager and owner, other parties involved in activities of non-profit organizations are, among the others, volunteers, donors, or clients.

In a nonprofit organization, it is unclear who should be regarded as a principal (Anheier, 2005; Brody, 1996; Miller, 2002; Ostrower \& Stone, 2006 in Stijn Van Puyvelde1. et.al. 2012). Although owner in the sense of shareholders are not found, there are stakeholders of the organization who have interests in the organization and their goals are influenced by activities of the nonprofit organization (Jegers, 2008), so that, sometimes, different stakeholders have different goals (Balser \& McClusky, 2005 in Stijn Van Puyvelde1 et.al. 
2012).It causes that a nonprofit organization has multiple frameworks of several principals (Jegers, 2008; Steinberg, 2010).

Steinberg (2010) applied the agency theory in nonprofit organizations and concluded that the existence of multiple actors with different goals in an organization will lead to potential agency conflicts in the nonprofit accountability. Therefore, perspectives of other theories to complement the agency theory are needed (Eisenhardt, 1989, Steinberg, 2010).

The agency theorists argue that difference in ownership structure is important for modern firms in facing agency issues (Jensen \& Meckling, 1976). The agency conflict occurs due to difference of interests, especially in a particular context, namely it depends on competitive factor between owner and manager of the company (Boyd, 1994, 1995 in Lee, Neill and Lee, 2009). Lane, Cannella, Lubatkin (1998) in (Lee, Neill and Lee, 2009) stated that predictions of agency theory, especially agency conflicts, will not occur when managerial interest and stakeholders's interest are not in conflict. Structuresof Japanese corporate ownershipsare often a manifestation of affiliation relationship between company and supplier, keiretsu members (business group), so that conflict of interest between manager and shareholder tends to decrease in the presence of tie binding managers and shareholders (Aoki, Patrick, \& Sheard, 1994; Kester, 1991).

Applicable economics theory for analyzing relationships between the actors is the agency theory because relation of principal can be defined as a contract in which one or more persons (principal) involves another person (agent) to perform some services on behalf of a principal who delegates some decision-making authority to the agent (Jensen \& Meckling, 1976, p. 308).

Stewardship theory is also an alternative used to reduce agency conflicts (Davis, Schoorman, \& Donaldson, 1997; Fox \& Hamilton, 1994) with argument that the interest of manager is in harmony with the interest of others. When this is so, corporate governance mechanism is insignificantly influential (Barney \& Hansen, 1994).In other words, it works well according to the applied rules in managing the company and an opportunistic manager will not occur. Thus, experts expand study of the agency by examining application of the agency theory supported by the stewardship theory in the context of relationship between principal and agent.

Similar to the context of the agency theory, stewardship theory also focuses on aligning goals between principal and agent (Arthurs and Busenitz, 2003). Since the stewardship theory assumes that goals of principal and agent are aligned or equal, so it also provides information on relationship between principal and agent, but the findings showed that the stewardship theory cannot clearly explain the relationship because it implicitly assumes subordination of agency goal, and the agent is very obedient and ignoring his own interests to serve the principal's ones. Lane, Cannella, and Lubatkin in (Lee, Neill and Lee, 2009) argued that the stewardship theory proves to be an appropriate perspective for government-owned companies. While Weick (1979) stated that there is no accurate theory in all contexts, but there is an appropriate theory in some contexts. 
The agency theory and stewardship theory are also inseparable from intellectual capital. Most systems of companies use intellectual capital. However, many people who are working in organizations and businesses are unaware of it (Zanjirdar et al, 2008). The concept of intellectual capital has often been discussed, but it is not well defined and different statements/results in interpreting this concept are still found.

Stewart (1997) stated that intellectual capital is a set of knowledge, information, intellectual property, experience, competence and organizational learning. Intellectual capital has no physical properties and it is an invisible asset acquired by the use of human resources, organizational operations and external relationships. Thus, intellectual capital is able to create value of an organization and the value indicates a good phenomenon within the organization and no merchantability (Ross and Baroness (2005) in (Moeinfar, Amouzesh and Mousavi, 2013))

Information of intellectual capital is required for the principal to make better business decisions ( $\mathrm{Li}$ et al, 2008) in (Moeinfar, Amouzesh and Mousavi, 2013). If the investors/principals have more information to invest, then they get more knowledge about financial performance of the company. It can increase value of the company. Intellectual capital disclosure provides valuable information to investors, because it will lead to minimization of uncertainty about the future prospects of the company (Bach, 2003).According to the agency theory, companies have high agency costs and it is expected to minimize by improving corporate governance mechanism and improving information disclosure.

Purpose of the present paper is to discuss agency problem and limitation of agency theory related to relationship between principal and agent. Second, analyzing stewardship theory and its very limited paradigm in explaining relationship between principal and agent. Third, theoretical limitation is found in explaining relationship of principal and agents. The paper combines agency theory and stewardship theory with intellectual capital in minimizing agency conflict to enhance value of a firm in the perspective of ownership structure.

\section{Literature Review}

\section{Agency Theory and Corporate value}

Agency Theory has been widely used in various disciplines. The Agency theory discusses situations in which principals delegate their authority of control and decision-making for particular task to the agent (Eisenhardt, 1989); Mitnick, 1973; Ross, 1973). Researches on the agency theory by scientists such as Ross (1973, 1979), Mitnick (1973, 1975), Jensen and Meckling (1976) and Eisenhardt (1989) can substantially increase our understanding of how agency theory can provide insight into economic field (Stock, 1997). Researches on agency theory were also found in Indonesia, the experts explained relationships in various disciplines such as economics and finance (Sappington, 1991), information systems (Mahaney and Lederer, 2003), and management science (Eisenhardt, 1985; 1988 in (Fayezi, O'Loughlin and Zutshi, 2012.) The agency theory had also been examined by experts for different types of companies, such as family company (Blanco-Mazagatos, de Quevedo-Puente and 
Delgado-García, 2016), non-profit company (Steinberg, 2010), private companies (Maksimov, Wang and Luo, 2017)..

A study of management relationships arises because of the necessary situational factors, organizational structures, individuals with psychological profiles and risk preferences. Particularly in the organizational structure, there will be empowerment and autonomy among members causing the management relationships evolve as opposed to agency relationships relying on control and monitoring (Davis et al, 1997). The agency relationship occurs when the principal delegates his work to the agents. In doing their tasks, the agents make the interests of the principals as main priority or they behave as representative of the principal such as maximizing profits, but personal interests of the agents are still found. (Jensen and Meckling (1976), Ross, (1973), Eisenhardt, (1989) in (Fayezi, O'Loughlin and Zutshi, 2012) asymmetric information is found resulting in agency conflicts. The information asymmetry refers to less informed principals of company from the agents and lack of expertise and competence in part of the principal in managing of the company. The Agent with more expertise leaves the principal and gives little or incomplete information to him. The principal has difficulty in monitoring, because incomplete information tends to be very costly and mostly unavailable (Eisenhardt, 1989; Sharma, 1997).In such condition, agency problems can be moral hazard and adverse selection. Thus, the efficiency of managing agency issues is also related to information acquisition, conflict of interest, moral hazard and adverse selection (Fleiser 1991 in (Fayezi, O’Loughlin and Zutshi, 2012).

According to Jensen and Meckling (1976), the focus of agency theory that can minimize agency conflict is in determining contracts governing relationships of principal and agent. The contract idea is used as metaphor in describing relationships of principal and agents in which incentives, payroll and commissions cause the emergence of agency cost. In this case, the agency theory is an incentive-based mechanism in controlling performance-based governance. The mechanism is most suitable for conditions under which behaviour of the agent depends on the costs incurred and results in impact of large expenditures (Eisenhardt, 1985). On the other hand, remedial governance mechanism based on disclosure of agency behavior and actions through information systems depend on the establishment of rules and procedures, such as reporting status, budgeting, financial systems, performance, and monitoring of agency behavior based on the remedial (Eisenhardt, 1989; Zsidisin and Ellram, 2003). Therefore, in this case, the agency theory determined in organizational mechanism is utility of pro-organizational and collective behavior(Davis et al., 1997) that isdifferent from an untrustworthy opportunistic agent who will not make decisions for the best interests of the organization but to satisfy his personal needs in meeting the organization demands. The utility mechanism results in alignment of interests between principals, organizations and employees (Davis et al., 1997). Eisenhardt (1989) stated that, generally the principal would also minimize agency costs by monitoring and supervising behaviorof the agents during they work to maximize rewards.

Development of the agency theory is largely based on two approaches of research, namely the classical approach of principal-agent relationship and positivist agency theory. The classical approach to an understanding of agency theory is to follow path of principal-agent 
relationships assuming that principals and agents will seek to maximize their positions written in the contract. Development of research on the agency theory in economic field is to link personal interests, limited rationality and risk aversion and agents as the main determinant in building the relationship (Eisenhardt, 1989). Normative researches on the agency theory have been also conducted in Indonesia aligning the interests of principal and agents. This positivist approach has contributed to our understanding of the apparent behavior of the agency theory in organizations (Mitnick, 2006). According to Mitnick (2006), both approaches help managers to understand complexity of the agency theory and its attributes. However, empirically the findings of researches on principal-agent relationship have been inadequately implemented in company/organization (Jensen, 1983).

The agency theory with a positivist approach has evolved to address shortcomings found in research of agency, particularly the complexity of agency conflict of firms (Eisenhardt, 1989). The positivist approach seeks to synthesize various fields of sciences, namely political, legal institutions and sociology sciences into a single framework, and seeks to explain how the relationships in business and government, and managing them effectively (Shapiro, 2005 in (Fayezi, O'Loughlin and Zutshi , 2012).

\section{Stewardship Theory - Corporate value}

(Zahra et al., 2008) suggests that the stewardship theory has different/contrast perspectives than the agency theory, especially in motivation and control issues of businesses considering the relationship between principal (owner) and agent (manager) (Daviset al.,1997). According to assumption of the stewardship theory, manager prefers the interests of organization rather than economic interests of individuals in order to achieve strategic mission of the organization and it affects intrinsic satisfaction of employees. Stewardship behavior is enhanced through individual empowerment, rather than through agency-based governance arrangements emphasizing direct monitoring and financial control systems (Davis et al, 1997).

The Stewardship theory with psychological and sociological roots is designed to explain situations in which manager as an agent acts on the interests of the principal (Donaldson \& Davis, 1989, 1991). According to the theory, manager will behave for the common interests. When the interest of the principal is not in harmony with the interest of the agent, then the agent will try to work together rather than to conflict due to he feels that the common interest and to behave in accordance with the principal behavior is a rational consideration because the ownership is more oriented to effort of achieving organizational goals.

The stewardship theory assumes that a strong relationship is found between the success of an organization and satisfaction of the principal. The agent will protect and maximize prosperity of the organization with good performance of the company, so that the utility function will be maximized. An important assumption of the stewardship theory is that managers (agents) will align their goals according to the owner (principals)'s ones. However, it does not necessary mean that the agent does not have his own necessities of life. 
The ability of a company to display strategic flexibility is often a function of organizational structure and culture (Roca-Puig, Beltrán-Martín, Escrig-Tena, \& Bou-Llusar, 2005; Worren, Moore, \& Cardona, 2002; Young-Ybarra \& Wiersema, 1999 in (Zahra et al., 2008) emphasizing development of human capital and employee involvement (e.g., Roca-Puig et.al in Shaker A. Zahra, 2017). Companies/ organizations oriented to stewardship theory management stated that employee empowerment can help owners to direct managers toward stewardship policies rather than self-serving behavior of the agents (Daviset al., 1997). Strategy of increasing employee commitment to organizational goals can provide a consistent motivational relationship between the role of the organization and the role of the employee. Employee's commitment is needed ina condition of dynamic environment (Eddleston et al., 2008). In such a context, trusting relationship between employee and organization, collaboration, adaptability and helping are characteristic of organizational culture that can help support organizational adjustment to global competition (Collins \& Smith, 2006). Although the degree of control/supervision is one of the most appropriate factors in corporate governance, but organizations that are facing environmental change with high levels of uncertainty and risks, then involvement, commitment and trust that are parts of stewardship theory can contribute positively to the level of organizational performance.

In the context of stewardship theory, managers are usually willing to innovate, take risks and explore new strategic options without fear of losing a job or undermining their professional or personal position in the company. Corporate culture is shaped by many factors including the values of founders and managers, human resource practices, and psychological contracts between the company and its members. Davis et al. (1997) suggested that a collectivist approach is an important feature of an organizational culture practicing an effective stewardship. Individual culture can hamper organizational efforts aimed at pursuing opportunities. While organizational culture emerges over time and reflects the values of the founders, companies are still able to influence their culture directly through their choices in human resource practices.

The stewardship theory is partially disseminated in response to harsh criticism directed at generalization and universal application of the agency theory viewing individual characteristics and motivations solely based on utility considerations (Cuevas-Rodríguez, Gomez-Mejia and Wiseman, 2012), and in perception of the agency theory, individuals are more self-interested (Argyris, 1973; Ferraro et al., 2005). Many studies on the topic of ownership structure examined power of the superior over the agency theory (Donaldson and Davis, 1991), mostly used both focused on examination and reconciliation of incompatibilities with the agency theory (Arthurs and Busenitz, 2003; Le Breton-Miller and Miller, 2009). Perspective of the stewardship theory presents a different model, namely psychology and sociology-based human capital to gain their utilities that are not self-interested in organizational and collective behavior(Davis et al., 1997). In contrast to an opportunistic agent, in the stewardship theory, employees are trustworthy and they will make decisions for the best interest of the organization and satisfy their personal needs by meeting the demands of the organization resulting in alignment of the interests of principals, organizations and employees (Davis et al., 1997). Ownership relations can only emerge in 
situational factors of the required organizational structure, and as an individual has an appropriate psychological profile and risk preferences. Based on the theories development, the stewardship theory is in opposition to the agency theory that relying on control and supervision (Davis et al, 1997).

\section{Intellectual Capital- Corporate value}

Researches within the scope of companies have undergone significant evolution. In the academics world, theory of company has been tested from various perspectives such as corporate governance, ownership structures, financial structures, resource-based views, and a knowledge-based outlook. Recently, there has been a paradigm shift toward intangible asset relations with special emphasis on the role of intellectual capital (IC) in determining performance and value creation. Researches on ICs, according to some experts, are complementary to the traditional view of financial structure (Modigliani \& Miller, 1958) and, scientific development of the ownership structure was initiated by Berle and Means (1932) and continued by Jensen and Meckling (1976), Fama and Jensen (1983), Jensen (1989), Morck, Shleifer, and Vishny (1988), and more recently by La Porta, Lopez-de-Silanes, and Shleifer (1999), Faccio and Lang (2002), and Dick and Zingales (2004).

The development of literature on management science and intellectual capital aims for creation of corporate value (Williams, 2001; Bontis, 2003). Interaction between tangible assets and ICs can be useful for two things, namely value of a company depends not only on capital and financial aspects and efficiency of stock market information but also on disclosure of information about IC management. Viewed from a financial perspective, researches on IC lead to corporate judgments associated with ownership structures and intellectual capital. In the financial aspect, a paradigm shift has been found in creation of corporate value from the traditional view seeing that the theory of ownership structure is a theory in the creation of corporate value to the view of modern management of the corporate value creation with its wider scope including not only the ownership structure but also corporate governance, interactions of assets, relational networks and human capital (Zanda, Lacchini, \& Oricchio, 1993).

Today, researches in Indonesia have included the importance of human capital, and its interaction with tangible assets in considering companies to innovate in the face of global competition so as to increase the value of the company (Grossman \& Hart, 1986; Hart, 1995; Hart \& Moore, 1990, 1994).

Some empirical studies showed impacts of intangible assets on both financial performance and stock returns of a company. Bornemann, Knapp, Schneider, and Sixl (1999) in (Celenza and Rossi, 2013) stated that companies managing their ICs will be more effective in creating corporate value.

Stewart (1997) stated that intellectual capital is a "useful pack of knowledge." In contrast, Petty dan Guthrie (2000) suggested the intellectual capital with a sharper meaning. Further, they argued that ICs play a role in determining corporate value and in improving economic performance of a nation. In the literature study, there has been also a widely accepted notion 
of a strong relationship between IC and corporate's market values. For example Lev and Zarowin (1999), Lev (2001), and Lev dan Radhakrishnan (2003) focused on the gap between market value and book value. In general, not only financial variable but also intellectual capital that is playing roles in the creation of corporate value.

Collectively, intellectual capital refers to all resources determining value of a corporate and its competitiveness. In the perspective, human resources is called non-financial asset. In article titled Intellectual Capital Taxonomy (2002), Paolo Magrassi defines human capital as knowledge and competence of an enterprise and as collective knowledge of employees who contribute to an organization. Although recently, many experts have been researching intellectual capital and how it is managed, there have been a little works describing and defining the concept. The intellectual capital can include skills and knowledge developed by a company about how to produce goods and services. Therefore, intellectual capital is not just organizational knowledge, but also industrial knowledge that is a combination of cognitive and intuitive knowledge/ experience.

Intellectual Capital consists of 1) Relationship Capital (all business relationships with external parties such as suppliers, partners, clients, vendors, etc.), 2) Human Capital (knowledge and competence of a company's employees), 3) organizational governance such as information systems, policies and procedures, intellectual property rights) (Sid Adelman, 2010).

Intellectual capital can also be interpreted as a tool needed to explore opportunities and to manage threats in life. Many experts said that intellectual capital play very great role in adding value to an activity. Various companies gaining excellence and advantages are those that continue to develop their human resources (Ross, et.al, 1997). Human beings have proactive and innovative characteristics to manage the very rapid changes in their living environment (economic, social, political, technological, legal, etc.). Those who cannot adapt to this super-fast change will be in trouble. In conditions marked by super-fast changes, human beings must continue to expand and sharpen their knowledge and develop their creativities to innovate. Intellectual capital lies in the willingness to think and ability to think something new, then intellectual capital is not always determined by a high level of formal education.

\section{Integration of The Agency Theory -The Stewardship Theory - Intellectual Capital -Corporate Value}

Normatively, the goal of corporate financial management is to increase the value of the firm that is reflected in its stock price (Fama, 1978; Wright and Ferris, 1997; WalNer 2000; and Qureshi, 2006). An increased corporate value means a maximization of wealth or prosperity of shareholder (Martin, et al., 1994). Goals of a company can be achieved through implementation of cautious and appropriate financial management functions, considering every financial decision will affect other financial decisions and later, it will affect the value of the company (Jensen dan Smith, 1994; Fama dan French, 1998). Function of corporate financial management regarding corporate decision- making consists of investment decisions, funding decisions, and dividend policies. The optimal combination of these decisions will 
maximize corporate value because they are connected to each another (Mbodja and MuNhrejee, 1994; and Qureshi, 2006).

Findings of other researches indicated that intellectual capital is also capable of creating added value for companies (Pulic, 1999). The findings support the view that intellectual capital is a very important resource for companies. Bontis (1998) stated that intellectual capital includes knowledge of all employees, organization and employees capabilities based on human capital, structural capital and customer capital in creating added value and leading to sustainable competitive advantage. In this paper, intellectual capital is more emphasized on human capital consisting of intellectual, skill, creativity, work method combined with development of structural capital in applying and developing great ideas, having systems and procedures that support innovation so as to have a sportive culture allowing individuals to try new things, learn them, and be ready to fail (Bontis et al., 2000).

The stewardship theory tends to prioritize an enhanced stewardship behaviorby empowering individuals in human capital development and employee involvement (Puig et.al in (Zahra et al., 2008) Shaker A. Zahra, 2017). Companies/organizations oriented to management of stewardship theory argued that employee empowerment can help owners to direct managers toward stewardship policies rather than self-interested agency actions (Davis, et. al., 1997).The stewardship theory reinforces the intellectual capital theory regarding employee involvement in improving performance of companies by giving priority to individual empowerment in both innovation and skill aspect and knowledge development aspect. Both theories support the agency theory in studying corporate management in order to enhance the corporate value. For achievement of this purpose, management is carried out separately by appointing a person who is granted with full duty and authority to manage the organization as written in the contract including incentives, payroll and commissions. In this case, the agency theory is a mechanism to control performance-based governance through incentives, which best suits for conditions of the agent's behavior depends on the costs incurred and impacts on large expenditures (Eisenhardt, 1985). On the other hand, remedial governance mechanisms based on disclosure of behavior and actions of the agents through information systems depend on the establishment of rules and procedures, such as reporting status, budgeting and financial systems, performance and monitoring behaviorof the agents based on the remedial (Eisenhardt, 1989; Zsidisin and Ellram, 2003).

According to Jensen and Meckling (1976), focus of the agency theory to minimize agency conflict is to determine a contract governing relationships of the principals and the agents regarding to funding. The notion of contract is used as metaphors in describing relationships the principals and the agents through: 1) the principals are able to align the interests and personal goals of the agents by offering contracts whereby the compensation scheme is changed from business-based salaries to outcome-based salaries so that the principals and the agents have a common interest in organizational performance (Crocker \& Slemrod, 2007; Holmström, 1979; Shavell, 1979); 2) The principals do a tight monitoring to the agents in order to improve their information so as to reduce working efforts (Chang \& Lai, 1999; Dickinson \& Villeval, 2008; Frey, 1993); 3) Combining the agency theory and the stewardship theory as an alternative to management theory in managing a company, so the 
managers tend to make maximum benefit to the organization rather than to prioritize their own goals and the agent must have ability, commitment and service as expected by the principal; 4) Combining the agency theory and intellectual capital, especially in human capital and structural capital, so that the agents have competence and skills in organizational governance and they can work in accordance with established mechanisms and rules.

Although the agency theory is the dominant paradigm underlying most of the corporate governance literature, then in attempts of enhancing the corporate value, authors combine it with the stewardship theory and the intellectual capital theory.

Based on this paper, performance differences can be seen, especially in the agency theory if factor of personal interest of the agents arise, then it can be a constraint/obstacle. However, the important thing in the agency theory is authority granted to the agent to perform actions in the interests of the owner. The agency theory produces an important way of explaining the conflicting interests between the owners and the managers. It supported by the stewardship theory and intellectual capital theory, so that the combined theories can support the theory of ownership.

According to Davis, Schoorman, and Donaldson (1997) and Sundaramurthy and Lewis (2003), the agency theory and the stewardship theory, in particular the relationship between principal and agent, have different assumptions and models. The author adds Intellectual Capital in the ownership relationship. There are differences in various dimensions between the agency theory, the stewardship theory and the intellectual capital as can be seen in the table below. 


\section{Ml Macrothink}

Table. Differences between the Agency theory, the Stewardship theory and the Intellectual Capital theory

\begin{tabular}{|c|c|c|c|c|}
\hline No & Dimensions & $\begin{array}{c}\text { The Agency } \\
\text { Theory }\end{array}$ & $\begin{array}{c}\text { The Stewardship } \\
\text { Theory }\end{array}$ & $\begin{array}{c}\text { The Intellectual Capital } \\
\text { Theory }\end{array}$ \\
\hline 1 & Theoretical bases & Economics & $\begin{array}{l}\text { Psychology and } \\
\text { sociology }\end{array}$ & $\begin{array}{l}\text { Human capital, structural } \\
\text { capital, relation capital }\end{array}$ \\
\hline 2 & Approach & Supervision & Trust & $\begin{array}{l}\text { Skill, competence, } \\
\text { innovation, mechanism, } \\
\text { governance, culture }\end{array}$ \\
\hline 3 & $\begin{array}{l}\text { Relationship of } \\
\text { Principal-Agent }\end{array}$ & $\begin{array}{l}\text { Conflict is } \\
\text { found }\end{array}$ & Compatible & Flexible \\
\hline 4 & $\begin{array}{l}\text { Motivation of the } \\
\text { Agent }\end{array}$ & Extrinsic & Intrinsic & Intrinsic \\
\hline 5 & $\begin{array}{l}\text { Organisasional } \\
\text { Identification }\end{array}$ & $\begin{array}{l}\text { Low } \\
\text { Identification }\end{array}$ & High Identification & High Identification \\
\hline 6 & HR Behavior & Individual & Group/Collective & Individualand group \\
\hline 7 & $\begin{array}{l}\text { Governance } \\
\text { mechanism }\end{array}$ & $\begin{array}{l}\text { Monitoring and } \\
\text { incentive }\end{array}$ & $\begin{array}{l}\text { Structural } \\
\text { empowerment }\end{array}$ & $\begin{array}{l}\text { Resource Development } \\
\text { and structural } \\
\text { empowerment }\end{array}$ \\
\hline
\end{tabular}

Based on the differences mentioned above, it can be seen that the three theories are complementary to each other in managing an organization/company. Davis et al. (1997) and Tosi et al. (2003) stated that organizations need the theories above in explaining the relationship of principal-agent so that goal of the company in enhancing the corporate value can be met.

Result of the present paper is integration of intellectual capital theory, stewardship theory and agency theory that is necessary to explain management aiming at enhancing corporate value. Some studies found that the use of the agency theory, namely independent leadership has a high firm performance. In another studies, the stewardship theory also found a high performance of companies. Likewise, in the study of intellectual capital theory, it produced high corporate performance impacting on the enhanced corporate value. 


\section{Conclusion and Implementation}

A model had been presented suggesting that factors of human capital, structural capital and stewardship theory have effect on management of a company in perspective of agency in enhancing the corporate value.

The enhancement of corporate value reflected in prosperity of shareholders can be realized by separatingthe corporate management. Agency theory specifically discusses relationship between principal and agent and helps to understand conflict of interests that may occur between the principal and the agent. The agency theory seeks to establish formal relationships between the principals and the agents or the interested parties. This theory emphasizes a design of performance evaluation and rewards for managers to make them behaving positively or benefiting the company as a whole.

However, the agency theory does not apply in all situations, so an alternative model supporting improvement of corporate value is proposed, namely the stewardship theory specialized to human capital about managerial behavior and motivation and, theory of intellectual capital focused on human capital (skill, competence and innovation) and structural capital (governance, mechanism, culture). This paper adds to understanding about stewardship theory and intellectual capital theory by describing their theoretical terminologies and contribution.

Based on combination of the model, the manager who is choosing to behave as the owner/servant with awareness as the responsible person of the company conducts self-development and innovation. The principal also decides to create an agency relationship, a stewardship reinforced with intellectual capital, depending on the perception of the situation and the manager. If the manager or the principal feels that the other will behave actively (to survive), then the best benefits will be acquired by behaving as an agency, and the organization receives a fairly optimal return on its investment.

It is recommended that researches on stewardship theory with adding a relation capital into intellectual capital should be conducted in the future. Theoretical and empirical uniformity is needed to help researchers have a complete understanding of the stewardship theory and intellectual capital theory.

By combining the agency theory, the stewardship theory, the intellectual capital and empirical literature, author conclude about a more comprehensive main agent: a) he perspective of stakeholder theory indicates the importance of a framework with multi-principals; b) perspective of the stewardship theory indicates that situation in which the agent has the same interest as the principal or being motivated to act in the best interests of the principal also need to consider, and c) perspective of the intellectual capital shows that, the agent needs to do self-development so as to be more competent and be able to create new ideas and innovation to develop the company.

As a literature on organizational governance in academic field including economics, management, accounting, auditing and health care, author hope that this article can contribute 
to the establishment of an integrated theory of agency theory, stewardship theory and intellectual capital theory.

\section{References}

Albrecht, W. S., Albrecht C. C., \& Albrecht, C. O. (2004). Agency Theory fraud and corporate.pdf. Journal of Forensic Accounting, 109-130.

Anderson, S. B. et al. (2015). The effect of alternative accounting measurement bases on investors' assessments of managers' stewardship. Accounting, Organizations and Society, 46, 100-114. https://doi.org/10.1016/j.aos.2015.03.007.

Arthurs, J. D., \& Busenitz, L. W. (2003). E T \& P Limitations of Agency Relationship *. Entrepenruership Theory and Practice, 28(2), 145-162. https://doi.org/10.1046/j.1540-6520.2003.00036.x.

Bang, H. M., Zhou Koval, C., \& Wade-Benzoni, K. A. (2017). It's the thought that counts over time: The interplay of intent, outcome, stewardship, and legacy motivations in intergenerational reciprocity. Journal of Experimental Social Psychology, 73(November 2016), 197-210. Elsevier https://doi.org/10.1016/j.jesp.2017.07.006.

Blanco-Mazagatos, V., de Quevedo-Puente, E., \& Delgado-García, J. B. (2016). How agency conflict between family managers and family owners affects performance in wholly family-owned firms: A generational perspective. Journal of Family Business Strategy, 7(3), 167-177. Elsevier Ltd. https://doi.org/10.1016/j.jfbs.2016.07.003.

Boujelbene, M. A., \& Affes, H. (2013). The impact of intellectual capital disclosure on cost of equity capital: A case of French firms. Journal of Economics, Finance and Administrative Science, 18(34), 45-53. Elsevier. https://doi.org/10.1016/S2077-1886(13)70022-2

Bontis, Nick. (1997). Intellectual Capital Survey Questionnaire. Hamilton: Institute for Intellectual Capital Research: 1-7.

Bontis, Nick. (1998). Intellectual Capital : An Exploratory Study that Develops Measures and Models. Management Decision 36(2), 63-76. https://doi.org/10.1108/00251749810204142

Bontis, Nick et al.,. (2000). Intellectual Capital and Business Performance in Malaysian Industries. Journal of Intellectual Capital $1(1), \quad 85100$. https://doi.org/10.1108/14691930010324188

Le Breton-Miller, I., \& Miller, D. (2009). Agency vs. stewardship in public family firms: A social embeddedness reconciliation. Entrepreneurship: Theory and Practice, 33(6), 1169-1191. https://doi.org/10.1111/j.1540-6520.2009.00339.x

Celenza, D., \& Rossi, F. (2013). Ownership Concentration, Intellectual Capital, and Firm Performance: Evidence From Italy. China-USA Business Review, 12(12), 1157-1174.

Cerra, J. F. (2017). Emerging strategies for voluntary urban ecological stewardship on private property. Landscape and Urban Planning, 157, 586-597. Elsevier B.V. https://doi.org/10.1016/j.landurbplan.2016.06.016 
Chandler, J. (2017). Stewardship of offshore petroleum: Where is the value?. Marine Policy, 81(January), 64-70. https://doi.org/10.1016/j.marpol.2017.03.015

Chapin, F. S. et al. (2015). Ecosystem stewardship: A resilience framework for arctic conservation. Global Environmental Change, 34, 207-217. Elsevier Ltd. https://doi.org/10.1016/j.gloenvcha.2015.07.003.

Chrisman, J. J. et al. (2012). An agency theoretic analysis of value creation through management buy-outs of family firms. Journal of Family Business Strategy, 3(4), 197-206. Elsevier Ltd. https://doi.org/10.1016/j.jfbs.2012.10.003

Connelly, J. T. et al. (2017). A tale of two cities: Economic development, corporate governance and firm value in Vietnam. Research in International Business and Finance, 42(February), 102-123. Elsevier. https://doi.org/10.1016/j.ribaf.2017.04.002

Choudhury, Jyotirmayee. (2010). Performance Impact of Intellectual Capital: A Study of Indian it Sector. International Journal of Business and Management, 5(9), 72-80. https://doi.org/10.5539/ijbm.v5n9p72

Cuevas-Rodríguez, G., Gomez-Mejia, L. R., \& Wiseman, R. M. (2012). Has Agency Theory Run its Course?: Making the Theory more Flexible to Inform the Management of Reward Systems. Corporate Governance (Oxford), 20(6), 526-546. https://doi.org/10.1111/corg.12004

Clarke, $\mathrm{M}$ et al.,. 2010. Intellectual Capital and Firm Performance in Australia. Working Paper, University of Otago, New Zealand, 12, 2-23.

Eddleston, K. A., \& Kellermanns, F. W. (2007). Destructive and productive family relationships: A stewardship theory perspective. Journal of Business Venturing, 22(4), 545-565. https://doi.org/10.1016/j.jbusvent.2006.06.004

Fauver, L. and Naranjo, A. (2010). Derivative usage and firm value: The influence of agency costs and monitoring problems. Journal of Corporate Finance, 16(5), 719-735. Elsevier B.V. https://doi.org/10.1016/j.jcorpfin.2010.09.001

Fayezi, S., O'Loughlin, A., \& Zutshi, A. (2012). Agency theory and supply chain management: a structured literature review. Supply Chain Management: An International Journal, 17(5), 556-570. https://doi.org/10.1108/13598541211258618

Galeitzke, M. et al. (2016). Process-oriented Design Methodology for the (Inter-) Organizational Intellectual Capital Management. Procedia CIRP. Elsevier B.V., 40, 675-680. https://doi.org/10.1016/j.procir.2016.01.153

Giriati (2016). Free Cash Flow, Dividend Policy, Investment Opportunity Set, Opportunistic Behavior and Firm's Value: (A Study About Agency Theory). Procedia - Social and Behavioral Sciences, 219, 248-254. https://doi.org/10.1016/j.sbspro.2016.05.013

Gulrajani, N. (2017). Bilateral Donors and the Age of the National Interest: What Prospects for Challenge by Development Agencies?. World Development, 96, 375-389. Elsevier Ltd. 
https://doi.org/10.1016/j.worlddev.2017.03.021

Harrison, V. S. et al. (2017). Calling all volunteers: The role of stewardship and involvement in volunteer-organization relationships. Public Relations Review, 43(4), 872-881. Elsevier. https://doi.org/10.1016/j.pubrev.2017.06.006

Henssen, B. et al. (2014). The CEO autonomy-stewardship behavior relationship in family firms: The mediating role of psychological ownership. Journal of Family Business Strategy, 5(3), 312-322. Elsevier Ltd. https://doi.org/10.1016/j.jfbs.2014.01.012

Hojman, D. A., \& Miranda, Á. (2018). Agency, Human Dignity, and Subjective Well-being. World Development, 101, 1-15. Elsevier Ltd. https://doi.org/10.1016/j.worlddev.2017.07.029

Jax, K. (2015). Book Review. Basic and Applied Ecology, 16(8), 755. https://doi.org/10.1016/j.baae.2015.08.007

Jensen, J. P., \& Remmen, A. (2017). Enabling Circular Economy Through Product Stewardship. Procedia Manufacturing. The Author(s), 8(October 2016), 377-384. https://doi.org/10.1016/j.promfg.2017.02.048

Kluvers, R., \& Tippett, J. (2011). An exploration of stewardship theory in a Not-for-Profit organisation. Accounting Forum, 35(4), 275-284. Elsevier Ltd. https://doi.org/10.1016/j.accfor.2011.04.002

Lee, P. M., Neill, H. M. O., \& Lee, P. M. (2009). Ownership Structures and R \& D Investments of U . S . and Japanese Firms : Agency and Stewardship Perspectives. Academy of Management Journal, 46(2), 212-225. https://doi.org/10.2307/30040615

Li, T. and Zaiats, N. (2017). Corporate governance and firm value at dual class firms. Review of Financial Economics. Elsevier B.V. https://doi.org/10.1016/j.rfe.2017.07.001

Lopes-Costa, J. A. and Munoz-Canavate, A. (2015). Relational Capital and Organizational Performance in the Portuguese Hotel Sector (NUTS II Lisbon). Procedia Economics and Finance, 26(15), 64-71. Elsevier B.V. https://doi.org/10.1016/S2212-5671(15)00839-4

Maksimov, V., Wang, S. L., \& Luo, Y. (2017). Institutional imprinting, entrepreneurial agency, and private firm innovation in transition economies. Journal of World Business, 52(6), 854-865. Elsevier. https://doi.org/10.1016/j.jwb.2017.06.002

Manuel, D. G. et al. (2011). Using administrative data to measure the extent to which practitioners work together: "interconnected" care is common in a large cohort of family physicians. Open Medicine, 5(4), 177-182.

Masini, A., \& Menichetti, E. (2012). The impact of behavioural factors in the renewable energy investment decision making process: Conceptual framework and empirical findings. Energy Policy, 40(1), 28-38. Elsevier. https://doi.org/10.1016/j.enpol.2010.06.062

Mathias, B. D., Solomon, S. J., \& Madison, K. (2017). After the harvest: A stewardship perspective on entrepreneurship and philanthropy. Journal of Business Venturing, 32(4), 385-404. Elsevier Inc. https://doi.org/10.1016/j.jbusvent.2017.04.001 
Moeinfar, Z., Amouzesh, N., \& Mousavi, Z. (2013). Intellectual capital disclosure and corporate governance. International Journal of Business and Management, 4(7), 1961-1965.

Murphy, T. and O'Connell, V. (2017). Challenging the dominance of formalism in accounting education: An analysis of the potential of stewardship in light of the evolution of legal education. Critical Perspectives on Accounting, 44, 1-29. Elsevier Ltd. https://doi.org/10.1016/j.cpa.2016.06.001

Ni, J., Chu, L. K., \& Li, Q. (2017). Capacity decisions with debt financing: The effects of agency problem. European Journal of Operational Research, 261(3), 1158-1169. Elsevier B.V.https://doi.org/10.1016/j.ejor.2017.02.042

Ojalehto, bethany 1., Medin, D. L., \& García, S. G. (2017). Conceptualizing agency: Folkpsychological and folkcommunicative perspectives on plants. Cognition, 162, 103-123. Elsevier B.V. https://doi.org/10.1016/j.cognition.2017.01.023

Van Puyvelde, S. et al. (2012). The Governance of Nonprofit Organizations. Nonprofit and Voluntary Sector Quarterly, 41(3), 431-451. https://doi.org/10.1177/0899764011409757

Raharjo, E. (2007). Teori Agensi dan Teori Stewrship dalam Perspektif Akuntansi. Fokus Ekonomi, 2(1), 37-46.

Tamer, İ., Dereli, B., \& Sağlam, M. (2014). Unorthodox Forms of Capital in Organizations: Positive Psychological Capital, Intellectual Capital and Social Capital. Procedia - Social and Behavioral Sciences, 152, 963-972. https://doi.org/10.1016/j.sbspro.2014.09.351

Thaler, R. H. (1999). The End of Behavioral Finance. Financial Analysts Journal, 55(6), 12-17. https://doi.org/10.2469/faj.v55.n6.2310

Toivonen, A. and Toivonen, P. U. (2014). The transformative effect of top management governance choices on project team identity and relationship with the organization - An agency and stewardship approach. International Journal of Project Management, 32(8), 1358-1370. Elsevier Ltd. https://doi.org/10.1016/j.ijproman.2014.07.001

Wang, B. (2017). Ownership, institutions and firm value: Cross-provincial evidence from China. Research in International Business and Finance. Elsevier B.V. https://doi.org/10.1016/j.ribaf.2017.07.125

Welsh, D. H. B. et al. (2013). Perceptions of entrepreneurship across generations in family offices: A stewardship theory perspective. Journal of Family Business Strategy, 4(3), 213-226. Elsevier Ltd. https://doi.org/10.1016/j.jfbs.2013.07.003

Zahra, A. S. et al. (2008). E T \& P Commitment and Strategic Flexibility, 612, 1035-1055. 